\title{
Mortality of men in the Rhondda Fach 1950-80
}

\author{
LK ATUHAIRE, ${ }^{1}$ M J CAMPBELL, ${ }^{1}$ AL COCHRANE, ${ }^{2}$ M JONES, ${ }^{2}$ AND F MOORE
}

From the Department of Community Medicine and Medical Statistics, ${ }^{1}$ Southampton, and the MRC Epidemiology Unit, ${ }^{2}$ Cardiff, UK

ABSTRACT In a 30 year follow up study of 8526 men aged 20 and over in the Rhondda Fach $99.9 \%$ of the population was traced. Generally, the results are similar to those found in a 20 year follow up of the same subjects. Miners and ex-miners had an excess mortality compared with non-miners, but within the former only those who had had categories $B$ and $C$ pneumoconiosis showed a raised mortality. Category A pneumoconiosis was not associated with any excess compared with other miners and ex-miners. Two further aspects of the data relating to gastric cancer and progressive massive fibrosis will be examined in later reports.

The population of the Rhondda Fach has been described previously. ${ }^{1-3}$ For this publication the population has been slightly improved from that previously described by the elimination of a few duplicates, the retracing of men previously considered lost to follow up, and the continued examination of dates of birth on death certificates, compared with those stated when first seen. The population was not "flagged" at the National Health Service Central Registers, and the successful follow up was mainly due to "foot slogging." The follow up was at exactly 30 years from the date each individual was examined. The Registrar General's annual statistical reviews of England and Wales were used to calculate the expected number of deaths. The causes of deaths were grouped for coding as shown in the appendix. Much of the analysis was carried out using the program PYCL, which computed expected values from the number of personyears at risk and the external rates. ${ }^{4}$ Further analysis of trends was carried out using methods described by Breslow. 5

\section{Results}

SUR VIVAL RATES

Table 1 gives the details of the male population aged 20 or more available for analysis; the number not traced is satisfactorily small. Table 2 gives the population of miners and ex-miners by age and radiological categories of coalworkers' pneumoconiosis in 1950,

Received 4 March 1985

Accepted 15 April 1985 table 3 the numbers of deaths for all men by age, occupation, and radiological status, and table 4 the percentage surviving 30 years for the same groups. Table 5 gives the standardised mortality ratios (SMRs) for the same groups. For these we have used the rate per 1000 person-years, which is a slight improvement on the previous paper. ${ }^{3}$ As expected in such a large breakdown there are some maverick values in table 4 , which have been fully discussed. ${ }^{3}$

In table 5 one might have expected a gradual rise in SMRs from category 0 to category 3 as simple pneumoconiosis progressed due to dust exposure in working miners and the men became at increasing risk of developing progressive massive fibrosis, which progresses to categories $B$ and $C$ with their known high mortality. Instead, we find the SMRs for those with categories 0,1 , and 2 remaining unchanged. Those with category 3 SMR have risen a little, but the one surprise is the continuing relatively low SMR of those with " $A$ " shadows, which is similar to those for categories 0,1 , and 2 . One would have expected all the As to have become Bs or Cs in 30 years, leading to a high SMR. This anomaly will be discussed in detail in a later paper.

\section{SPECIFIC MORTALITY}

The SMRs by radiological status for the more common conditions are given in table 6 . The picture is similar to that found in the 20 year follow up-that is, high SMRs for bronchitis (see below) and low for carcinoma of the trachea, bronchus, and lung. The SMR for carcinoma of the large intestine is on the low side for non-miners but there is insufficient evidence to suggest that exposure to coal dust increases mortality 
Table 1 Men of Rhondda Fach by age and occupation in 1950-1 and number available for analysis

\begin{tabular}{|c|c|c|c|c|c|c|c|c|}
\hline \multirow[b]{2}{*}{$\begin{array}{l}\text { Age } \\
\text { groups }\end{array}$} & \multicolumn{4}{|l|}{ Non-miners } & \multicolumn{4}{|c|}{ Miners and ex-miners } \\
\hline & $\begin{array}{l}\text { Defined } \\
\text { population } \\
1950-1\end{array}$ & $\begin{array}{l}\text { Not } \\
x \text { rayed } \\
1950-1\end{array}$ & $\begin{array}{l}\text { Not } \\
\text { traced } \\
\text { at } 30 y\end{array}$ & $\begin{array}{l}\text { Xrayed and } \\
\text { available for } \\
\text { analysis }\end{array}$ & $\begin{array}{l}\text { Defined } \\
\text { population } \\
1950-1\end{array}$ & $\begin{array}{l}\text { Not } \\
x \text { rayed } \\
1950-1\end{array}$ & $\begin{array}{l}\text { Not } \\
\text { traced } \\
\text { at } 30 y\end{array}$ & $\begin{array}{l}\text { X rayed and } \\
\text { available for } \\
\text { analysis }\end{array}$ \\
\hline $\begin{array}{r}20-24 \\
25-34 \\
35-44 \\
45-54 \\
55-64 \\
65-74 \\
\geqslant 75 \\
\text { Total }\end{array}$ & $\begin{array}{r}492 \\
736 \\
447 \\
222 \\
148 \\
62 \\
32 \\
2139\end{array}$ & $\begin{array}{r}13 \\
33 \\
28 \\
23 \\
16 \\
11 \\
8 \\
132\end{array}$ & $\begin{array}{l}0 \\
4 \\
1 \\
1 \\
1 \\
0 \\
0 \\
7\end{array}$ & $\begin{array}{r}479 \\
699 \\
418 \\
198 \\
131 \\
51 \\
24 \\
2000\end{array}$ & $\begin{array}{r}325 \\
1148 \\
1346 \\
1338 \\
1170 \\
766 \\
294 \\
6387\end{array}$ & $\begin{array}{r}1 \\
8 \\
14 \\
13 \\
32 \\
58 \\
75 \\
201\end{array}$ & $\begin{array}{l}1 \\
2 \\
0 \\
0 \\
0 \\
1 \\
0 \\
4\end{array}$ & $\begin{array}{r}323 \\
1138 \\
1332 \\
1325 \\
1138 \\
707 \\
219 \\
6182\end{array}$ \\
\hline
\end{tabular}

Table 2 Miners and ex-miners by age and radiological category in 1950-1

\begin{tabular}{|c|c|c|c|c|c|c|c|}
\hline \multirow[b]{2}{*}{ Age } & \multicolumn{7}{|c|}{ Radiological category } \\
\hline & 0 & 1 & 2 & 3 & $A$ & $B C$ & Total \\
\hline $\begin{array}{l}20-24 \\
25-34 \\
35-44 \\
45-54 \\
55-64 \\
65-74 \\
\geqslant 75 \\
\text { Total }\end{array}$ & $\begin{array}{r}277 \\
717 \\
663 \\
691 \\
561 \\
325 \\
119 \\
3353\end{array}$ & $\begin{array}{r}25 \\
147 \\
157 \\
187 \\
165 \\
99 \\
29 \\
809\end{array}$ & $\begin{array}{r}17 \\
119 \\
174 \\
128 \\
105 \\
70 \\
13 \\
626\end{array}$ & $\begin{array}{r}1 \\
82 \\
120 \\
70 \\
46 \\
25 \\
4 \\
348\end{array}$ & $\begin{array}{r}2 \\
47 \\
89 \\
98 \\
78 \\
59 \\
13 \\
386\end{array}$ & $\begin{array}{r}1 \\
26 \\
129 \\
151 \\
183 \\
129 \\
41 \\
660\end{array}$ & $\begin{array}{r}323 \\
1138 \\
1332 \\
1325 \\
1138 \\
707 \\
219 \\
6182\end{array}$ \\
\hline
\end{tabular}

Table 3 Numbers of deaths of all men in 30 years by age, occupation and radiological category in 1950-1

\begin{tabular}{|c|c|c|c|c|c|c|c|c|c|c|c|c|}
\hline \multirow[b]{2}{*}{ Age } & \multicolumn{3}{|c|}{ Non-miners } & \multicolumn{9}{|c|}{ Miners and ex-miners } \\
\hline & $\begin{array}{l}\text { Total } \\
\text { traced }\end{array}$ & $\begin{array}{l}\text { Not } x \text { rayed } \\
1950-1\end{array}$ & Seen & 0 & $l$ & 2 & 3 & $A$ & $B C$ & $\begin{array}{l}\text { All } \\
\text { seen }\end{array}$ & $\begin{array}{l}\text { Not } x \text { rayed } \\
1950-1\end{array}$ & $\begin{array}{l}\text { Total } \\
\text { traced }\end{array}$ \\
\hline $\begin{array}{l}20-24 \\
25-34 \\
35-44 \\
45-54 \\
55-64 \\
65-74 \\
\geqslant 75 \\
\text { Total }\end{array}$ & $\begin{array}{r}40 \\
131 \\
183 \\
156 \\
138 \\
61 \\
32 \\
741\end{array}$ & $\begin{array}{r}2 \\
10 \\
17 \\
16 \\
16 \\
11 \\
8 \\
80\end{array}$ & $\begin{array}{r}38 \\
121 \\
166 \\
140 \\
122 \\
50 \\
24 \\
661\end{array}$ & $\begin{array}{r}29 \\
142 \\
313 \\
542 \\
547 \\
324 \\
119 \\
2016\end{array}$ & $\begin{array}{r}5 \\
27 \\
79 \\
146 \\
158 \\
97 \\
29 \\
541\end{array}$ & $\begin{array}{r}3 \\
22 \\
96 \\
105 \\
103 \\
70 \\
13 \\
412\end{array}$ & $\begin{array}{r}0 \\
22 \\
68 \\
51 \\
46 \\
25 \\
4 \\
216\end{array}$ & $\begin{array}{r}0 \\
11 \\
55 \\
76 \\
77 \\
59 \\
13 \\
291\end{array}$ & $\begin{array}{r}0 \\
14 \\
102 \\
144 \\
178 \\
129 \\
41 \\
608\end{array}$ & $\begin{array}{r}37 \\
238 \\
713 \\
1064 \\
1109 \\
704 \\
219 \\
4084\end{array}$ & $\begin{array}{r}1 \\
1 \\
7 \\
9 \\
31 \\
58 \\
75 \\
182\end{array}$ & $\begin{array}{r}38 \\
239 \\
720 \\
1073 \\
1140 \\
762 \\
294 \\
4266\end{array}$ \\
\hline
\end{tabular}

For comparison with the population of miners and ex-miners ( $x$ rayed in 1950-1) we could use the whole non-mining population or those $x$ rayed in $1950-1$. We decided the latter was more logical. In any case it makes little difference.

Table 4 Percentage of men by age and radiological category in 1950-1 surviving 30 years

\begin{tabular}{|c|c|c|c|c|c|c|c|c|c|c|c|c|}
\hline \multirow[b]{2}{*}{ Age } & \multicolumn{3}{|c|}{ Non-miners } & \multicolumn{9}{|c|}{ Miners and ex-miners } \\
\hline & $\begin{array}{l}\text { Total } \\
\text { traced }\end{array}$ & Not $x$ rayed & Seen & 0 & 1 & 2 & 3 & $A$ & $B C$ & Seen & Not $x$ rayed & $\begin{array}{l}\text { Total } \\
\text { traced }\end{array}$ \\
\hline $\begin{array}{l}20-24 \\
25-34 \\
35-44 \\
45-54 \\
55-64 \\
65-74 \\
\geqslant 75 \\
\text { Total }\end{array}$ & $\begin{array}{r}91.9 \\
82.1 \\
59.0 \\
29.4 \\
6.1 \\
1.6 \\
0.0 \\
65.2\end{array}$ & $\begin{array}{r}84.6 \\
69.7 \\
39.3 \\
30.4 \\
0.0 \\
0.0 \\
0.0 \\
39.4\end{array}$ & $\begin{array}{r}92 \cdot 1 \\
82 \cdot 7 \\
60 \cdot 3 \\
29.3 \\
6.9 \\
2 \cdot 0 \\
0.0 \\
67 \cdot 0\end{array}$ & $\begin{array}{r}89.5 \\
80.2 \\
52.8 \\
21.6 \\
2.5 \\
0.3 \\
0.0 \\
39.9\end{array}$ & $\begin{array}{r}80.0 \\
81.6 \\
49.7 \\
21.9 \\
4.2 \\
2.0 \\
0.0 \\
33.1\end{array}$ & $\begin{array}{r}82.4 \\
81.5 \\
44.8 \\
18.0 \\
1.9 \\
0.0 \\
0.0 \\
34.2\end{array}$ & $\begin{array}{r}100.0 \\
73.2 \\
43.3 \\
27 \cdot 1 \\
0.0 \\
0.0 \\
0.0 \\
37.9\end{array}$ & $\begin{array}{r}100.0 \\
76.6 \\
38.2 \\
22.5 \\
1.3 \\
0.0 \\
0.0 \\
24.6\end{array}$ & $\begin{array}{r}100.0 \\
46.2 \\
20.9 \\
4.6 \\
2.7 \\
0.0 \\
0.0 \\
7.9\end{array}$ & $\begin{array}{r}88.5 \\
79.1 \\
46.5 \\
19.7 \\
2.6 \\
0.4 \\
0.0 \\
33.9\end{array}$ & $\begin{array}{r}0.0 \\
87.5 \\
50.0 \\
30.8 \\
2.1 \\
0.0 \\
0.0 \\
9.5\end{array}$ & $\begin{array}{r}88.3 \\
79.1 \\
46.5 \\
19.8 \\
2.6 \\
0.4 \\
0.0 \\
33.2\end{array}$ \\
\hline
\end{tabular}


Table 5 Thirty year mortality by occupation and radiological category in 1950-1 for age group 20-74

\begin{tabular}{|c|c|c|c|}
\hline Occupation/category & Observed deaths & $S M R$ & $95 \%$ Confidence limits for SMR \\
\hline $\begin{array}{l}\text { Non-miners excluding those not } \\
x \text { rayed } 1950-1\end{array}$ & 637 & 99.0 & $91 \cdot 4,106 \cdot 8$ \\
\hline $\begin{array}{l}\text { Miners and ex-miners } \\
\text { Cat } 0 \\
\text { Cat 1 } \\
\text { Cat } 2 \\
\text { Cat 3 } \\
\text { Cat A } \\
\text { Cat B, C }\end{array}$ & $\begin{array}{r}1897 \\
512 \\
399 \\
212 \\
278 \\
567\end{array}$ & $\begin{array}{l}121 \cdot 2 \\
117 \cdot 8 \\
121 \cdot 2 \\
129 \cdot 6 \\
124 \cdot 3 \\
198 \cdot 1\end{array}$ & $\begin{array}{l}115 \cdot 8,126 \cdot 7 \\
107 \cdot 8,128 \cdot 2 \\
109 \cdot 6,133 \cdot 7 \\
112 \cdot 8,148 \cdot 3 \\
110 \cdot 1,139 \cdot 8 \\
182 \cdot 1,214 \cdot 8\end{array}$ \\
\hline
\end{tabular}

Table 6 Observed deaths and SMRs for some specific causes of death for age group 20-74

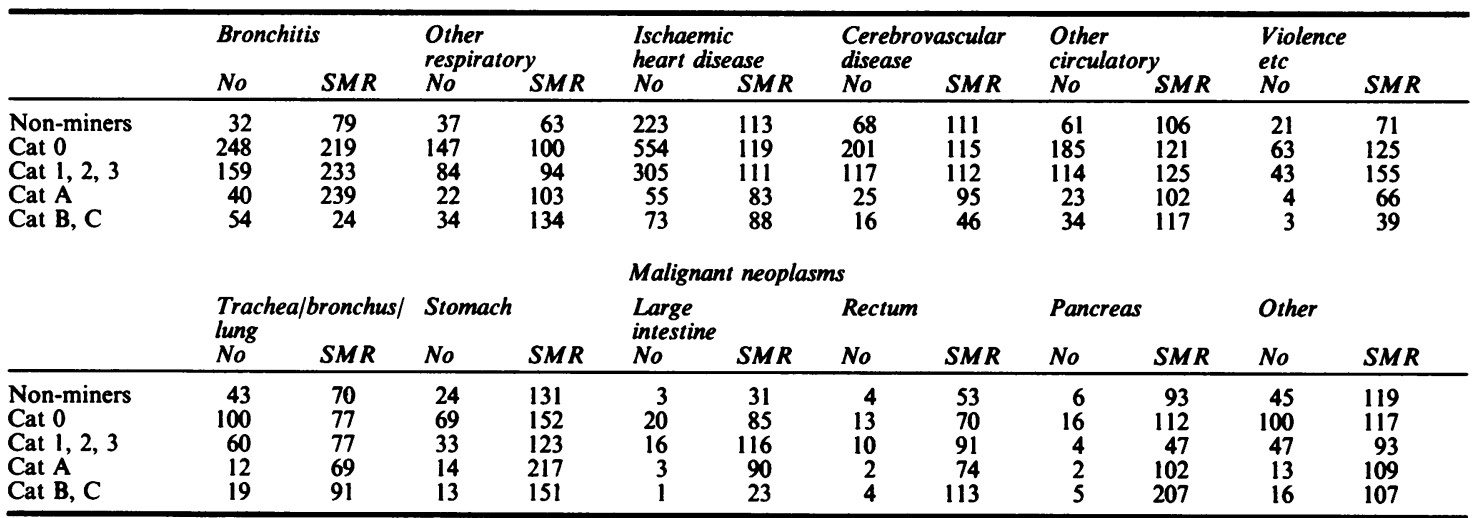

from this cause. For carcinoma of the pancreas, not considered in the previous papers, the data do not suggest that its incidence is increased by exposure to coal dust. The SMRs for gastric cancer appear bizarre, but will be discussed in detail in a subsequent paper.

The increased number of deaths in the 30 year follow up gives us the opportunity of investigating the problem of why the SMRs of categories $0,1,2$, and 3 are so similar, although the SMR for pneumoconiosis rises sharply with increasing category.

Although numbers of deaths from pneumoconiosis are low relative to other causes of death, it is possible that the SMR from a single cause or group of causes may fall in compensation. This possibility is explored in table 7, where it should be noted that the SMRs for pneumoconiosis are almost certainly too low. ${ }^{6}$ There are no statistically significant trends with increasing category of pneumoconiosis, except that of pneumoconiosis itself. Deaths from "other malignant neoplasms" show a consistent but not significant downward trend with increasing category.

\section{Discussion}

The results given in this paper may be compared with the equivalent results for the 20 year follow up. ${ }^{3}$ The remarkable result of the previous paper was the high mortality of miners and ex-miners when compared with non-miners. Subsequent research has shown that this excess is peculiar to the Rhondda Fach, ${ }^{6}$ and was not found in Leigh in Lancashire or Staveley in

able 7 Observed deaths and SMRs for some specific causes of death by simple pneumoconiosis for age group 20-74

\begin{tabular}{|c|c|c|c|c|c|c|c|c|c|c|c|c|c|c|c|c|c|c|c|c|}
\hline \multirow[t]{2}{*}{$\begin{array}{l}\text { ztegory of } \\
\text { teumo- } \\
\text { niosis }\end{array}$} & \multicolumn{2}{|c|}{$\begin{array}{l}\text { Pneumo- } \\
\text { coniosis }\end{array}$} & \multicolumn{2}{|c|}{ Bronchitis } & \multicolumn{2}{|c|}{$\begin{array}{l}\text { Other } \\
\text { respiratory }\end{array}$} & \multicolumn{2}{|c|}{$\begin{array}{l}\text { Ischaemic } \\
\text { heart disease }\end{array}$} & \multicolumn{2}{|c|}{$\begin{array}{l}\text { Cerebro- } \\
\text { vascular } \\
\text { disease }\end{array}$} & \multicolumn{2}{|c|}{$\begin{array}{l}\text { Other } \\
\text { circulatory }\end{array}$} & \multicolumn{2}{|c|}{$\begin{array}{l}\text { Violence } \\
\text { etc }\end{array}$} & \multicolumn{4}{|c|}{$\begin{array}{l}\text { Malignant neoplasms } \\
\text { Tracheal Stomach } \\
\text { bronchus/lung }\end{array}$} & \multicolumn{2}{|c|}{ Other } \\
\hline & No & $S M R$ & No & $S M R$ & No & $S M R$ & No & $S M R$ & No & $S M R$ & No & $S M R$ & No & $S M R$ & No & $S M R$ & No & $S M R$ & No & $S M R$ \\
\hline for trend* & $\begin{array}{r}14 \\
5 \\
20 \\
19 \\
6\end{array}$ & $\begin{array}{r}314 \\
398 \\
2152 \\
4009 \\
7\end{array}$ & $\begin{array}{r}248 \\
75 \\
60 \\
24 \\
0\end{array}$ & $\begin{array}{l}219 \\
232 \\
269 \\
203 \\
4^{203}\end{array}$ & $\begin{array}{r}147 \\
38 \\
32 \\
14 \\
0\end{array}$ & $\begin{array}{l}121 \\
110 \\
123 \\
114 \\
-05\end{array}$ & $\begin{array}{r}544 \\
143 \\
96 \\
66\end{array}$ & $\begin{array}{r}119 \\
112 \\
99 \\
135 \\
22\end{array}$ & $\begin{array}{r}201 \\
62 \\
40 \\
15\end{array}$ & $\begin{array}{c}115 \\
124 \\
107 \\
87 \\
71\end{array}$ & $\begin{array}{r}184 \\
50 \\
43 \\
21 \\
0\end{array}$ & $\begin{array}{l}121 \\
116 \\
132 \\
136 \\
37\end{array}$ & $\begin{array}{r}63 \\
17 \\
17 \\
9 \\
1\end{array}$ & $\begin{array}{l}126 \\
135 \\
173 \\
170 \\
9\end{array}$ & $\begin{array}{r}100 \\
22 \\
25 \\
13 \\
0 .\end{array}$ & $\begin{array}{l}77 \\
63 \\
91 \\
86 \\
34\end{array}$ & $\begin{array}{r}69 \\
15 \\
13 \\
5 \\
0\end{array}$ & $\begin{array}{l}153 \\
120 \\
137 \\
103 \\
4\end{array}$ & $\begin{array}{r}149 \\
39 \\
26 \\
12 \\
2\end{array}$ & $\begin{array}{r}95 \\
86 \\
75 \\
68 \\
.36\end{array}$ \\
\hline
\end{tabular}


Derbyshire. This 30 year follow up confirms this excess mortality of miners and ex-miners compared with the non-miners. The contrast with the nonminers emerges only after the age of 35 , and so may relate to conditions in the Rhondda before the Second World War.

The relatively high survival rate of miners and exminers aged 35-44 without pneumoconiosis which was apparent after 20 years has greatly diminished after 30 years, and so was possibly due to random variations. The almost complete mortality of those aged 55 and over has obscured differences in survival among radiological categories in these age groups.

The previous paper used a weighting method to compute the SMRs whereas the present paper uses a method that takes into account the person-years in each group, which is a slight improvement.

Since the SMRs for category 0 and categories 1-3 in table 6 are so similar it is reasonable to ask whether those in categories $1-3$ are protected in some way from deaths other than pneumoconiosis. The deaths from pneumoconiosis, however, are low relative to other causes, and random variation appears to account for any apparent trends in the other causes of death.

In general there is little change from the results of the 20 year follow up except for the two points about gastric cancer and the aetiology of PMF which will be discussed in subsequent papers. The value of the $\mathbf{3 0}$ year follow up is to re-emphasise the 20 year result, that those with category A pneumoconiosis in the Rhondda Fach did not suffer an increased mortality compared with other miners or ex-miners with or without pneumoconiosis. Nevertheless, miners and ex-miners had an excess mortality compared with non-miners.

We would however like to use this opportunity to make two general points.

(1) This survey achieved $99.9 \%$ follow up. It was done without flagging at NHSCR. (One of us (ALC) did not think he would live long enough.) The survey was not costly. The result was also not a flash in the pan. Two of us (ALC and FM) achieved similar figures in our seven 20 year follow up studies of random samples of men and women in England, Scotland, and Wales. Other epidemiologists using captive populations and flagging do not seem to bother to achieve similar figures. Flagging seems to have replaced foot slogging whereas it should be used to reduce it. We think that this is regrettable.

(2) The value of all follow up studies in the United Kingdom (and almot certainly in other countries) is much reduced by the low standard of death certification. The reckless use by the pathologists of the phrase "bronchitis and pneumoconiosis" is a crying example in this paper. ${ }^{7}$ We would like to make a plea for the better education of medical students, for consultants to be made responsible for death certificates signed by their juniors, and for pathologists to know the coding rules for death certificates, even though the deaths are eventually certified by coroners.

One of us (FM) was in receipt of a small grant from the National Coal Board for a few months work. $\mathrm{Mr}$ P Sweetnam (MRC, Cardiff) helped with the creation of the data set, and we are indebted to Mr P Winter (MRC, Southampton) for the use of the person-years at risk program PYCL.

\section{References}

${ }^{1}$ Cochrane AL, Cox JG, Jarman TF. Pulmonary tuberculosis in the Rhondda Fach. Br Med J 1952;ii:843-53.

${ }^{2}$ Cochrane AL, Carpenter RF, Moore F, Thomas J. The mortality of miners and ex-miners in the Rhondda Fach. Br J Ind Med 1964;21:38-45.

${ }^{3}$ Cochrane AL, Haley TJL, Moore F, Hole D. The mortality of men in the Rhondda Fach. Br J Ind Med 1979;36:15-22.

${ }^{4} \mathrm{Hill}$ ID. Computing man years at risk. Br J Prev Soc Med 1972;26:132-4.

${ }^{5}$ Breslow N. Elementary methods of cohort analysis. Int J Epidemiol 1984;13:112-5.

${ }^{6}$ Cochrane AL, Moore F. A 20 year follow-up of men aged 55-64 including coal miners and foundry workers in Staveley, Derbyshire. Br J Ind Med 1980;37:226-9.

${ }^{7}$ Cochrane AL, Moore F. Death certification from the epidemiological point of view. Lancet $1981 ; \mathrm{i}: 742-3$. 
Appendix

GROUPING OF CAUSES OF DEATH USED FOR SMRS

Cause of death ICD/6 to 1957

ICD/7 1958-67

ICD/8 1968-78

501,502

523,001

$241,470-527$

excluding

$501,502,523$

Ischaemic heart disease

Cerebrovascular disease

Other circulatory

Violence

Malignant neoplasm:

Trachea/bronchus/lung

Stomach

Large intestine

Rectum

Pancreas

Other
420,422

330-334

400-468

excluding

420-422

E800-999

162,163

151

153

154

157

140-205

excluding

$151,153,154$

$157,162,163$
490,491

515,010

460-519

excluding

490, 491, 515

410-414

430-438

390-458

excluding

410-414

430-438

E800-999

162

151

153

154

157

140-209

excluding

$151,153,154$

157,162
ICD/9 1979

and later

$490,491,496$

$500,502,505$

460-519

excluding

490, 491, 496

$500,502,505$

410-414

430-438

390-459

excluding

410-414

430-438

E800-999

162

151

153

154

157

140-208

excluding

$151,153,154$

157,162 